\title{
Experiences with Lean Management
}

\author{
Jan Frick \\ University of Stavanger 4036 Stavanger, Norway \\ http://www.uis.no
}

\begin{abstract}
The International Manufacturing Strategy Survey (IMSS) have collected data in 1992, 1996, 2000, and 2006. The paper does longitudinell studies on these data focussing on data relevant for Lean Management. We see that there has been an adoption of the Just in Time and Lean issues, but that there is still a way to go.
\end{abstract}

\section{Introduction}

Lean Management emerged (Jones, 1990) as a "new" paradigm to provide competitiveness for companies. The term was new from studies in automobile industries, but most of the ideas were much older even if they here became presented in a new context.

The International Manufacturing Strategy Survey (IMSS) (Lindberg, Hörte, International Manufacturing Strategy Survey, \& Institute for Management of Innovation and Technology, 1994; Lindberg, Voss, \& Blackmon, 1998) became a team with partners in more than 20 countries that have gathered data in industrial companies in 1992, 1996, 2000, and 2005. The normal is one partner organization per country and there are partners in all continents except Africa. This makes the dataset unique in the sense that it both have subsets of data from more than 20 years and that it contains data from many parts of the industrialized world. Most of the partner organizations have used the data for journal papers, conferences, thesis, and student tasks. ((Acur, Gertsen, Sun, \& Frick, 2003; Crowe, Brennan, Coughlan, \& Dromgoole, 2003; Evensen, 2002; Gertsen, Sun, Riis, \& IPS - Integrated Production Systems, 1994; Klingan, 2000; Laugen \& Frick, 2002; Nyvoll, 2004; Skåle, 2000; Sun, 1996)) But most of these analysis have been based on only one set of the data.

This paper base the analysis on relevance for Lean issues. These data is present in all sets and countries, and these topics have been focused on in the industry in this period due to relations to popular conference issues. (Womack, Roos, \& Jones, 1991; Østebø, 2000) The Østebø thesis also shows that these issues are relevant for industries far from the automobile or general manufacting. In this case it was used for drilling wells for the offshore petroleum industry.

Please use the following format when citing this chapter:

Frick, J., 2008, in IFIP International Federation for Information Processing, Volume 257, Lean Business Systems and Beyond, Tomasz Koch, ed.; (Boston: Springer), pp. 249-256. 
The IMSS datasets contain much more data than we utilize here, but these were useful as a reference regarding the lean management. Regarding the reliability of the IMSS, we know that data collection took place in various circumstances and therefore does contain uncertainty, but we hope by selection to keep it as reliable as possible.

\section{Analysis and results}

The analysis of the IMSS datasets in this paper are based on simple statistics used on the longitudinal datasets. (Hedeker \& Gibbons, 2005) We have to remember that we have different companies (with few exceptions) in each dataset and the countries participating change from set to set. (Sun \& Hansen, 1992) This adds some considerations that are discussed in another paper. (Frick, 2006)

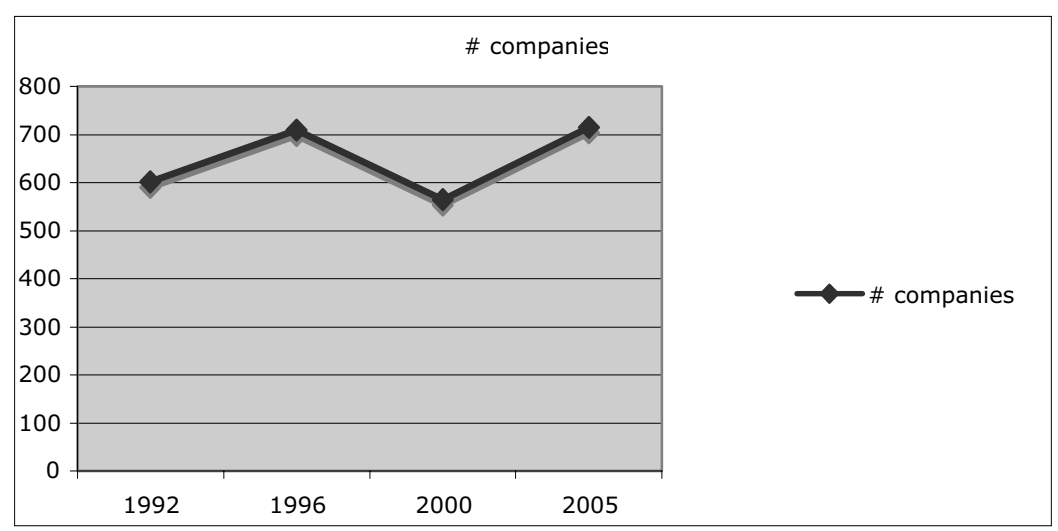

Fig. 1. The number of companies in each of the IMSS data collections

Figure 1 shows that the number of companies included in IMSS is different each time, but the differences are small when it comes to our discussion of cost numbers. The number of countries varies also with the highest number included in 1996, but for all four dataset the majority of companies and countries are European with some addition from Australia, Asia, and North and South America.

Figure 2 shows the trend of overhead cost as percentage of total cost. We see a clear decline over the period for the world. This was surprising since local cases have shown an increase in overhead due to increased automation even if the attention on lean management seems to have increased.

Figure 3 shows an increase in the use of preventive maintenance measured as a percentage of all maintenance cost. The use of preventive maintenance double from 1996 to 2000 and seems to be stable before and after this change.

It is interesting that the pattern shown in figure 4 hold an earlier improvement compared with figure 3. Figure 4 charts the percent of end-product deliveries done by JIT. There seems to be an adoption process where deliveries have as a general 
rule changed into a JIT concept before a similar change in the way to organize maintenance.

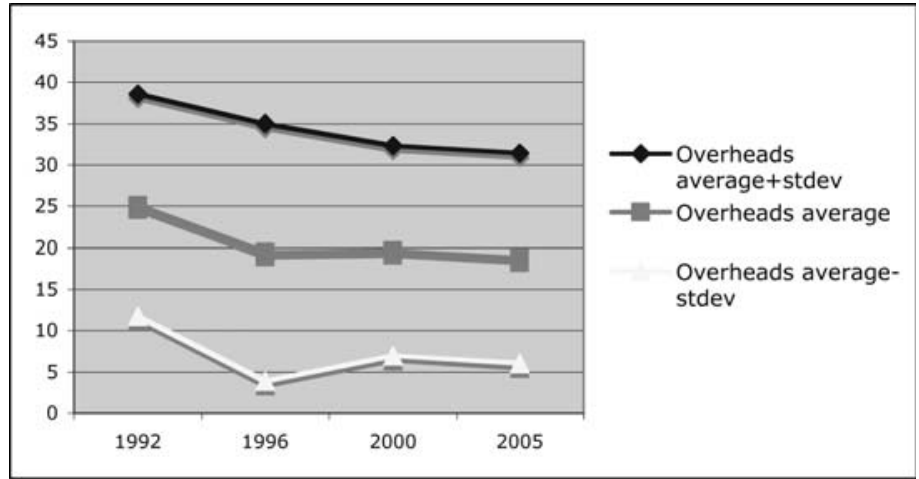

Fig. 2. The overhead as percent of total cost. It is showed as average and average plus and minus standard deviation. We see a clear declining trend

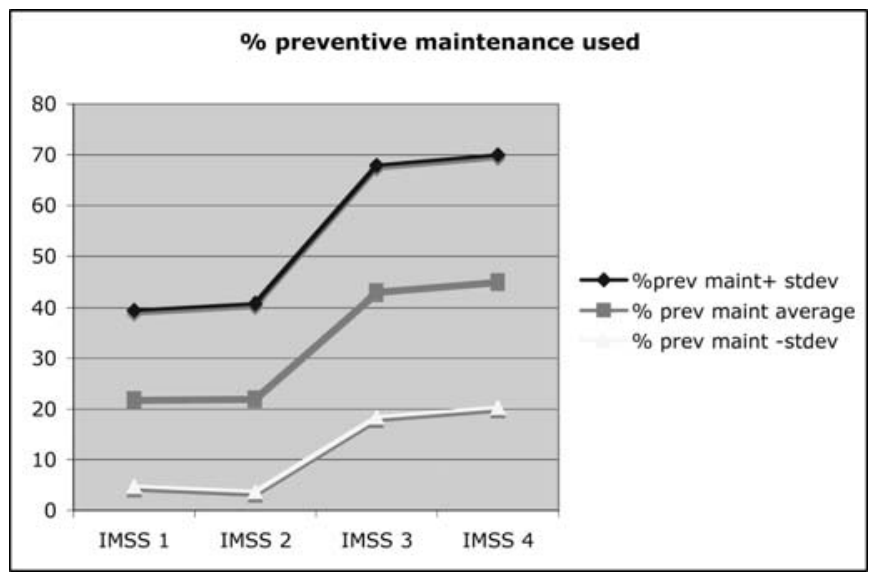

Fig. 3. The preventive maintenance as percent of all maintenance. It is showed as average and average plus and minus standard deviation

We see a similar development in the earliest three datasets in figure 5. Figure 5 shows the number of organizational levels in the company. Here we have the expected decline from IMSS 1 to IMSS 3. But, with IMSS 4 we see a change in the trend. Instead of a continued decrease in the number of organizational levels, we find an increase both in the average and in the standard deviation. We have no explanation for this change. (Sun, 1993). 


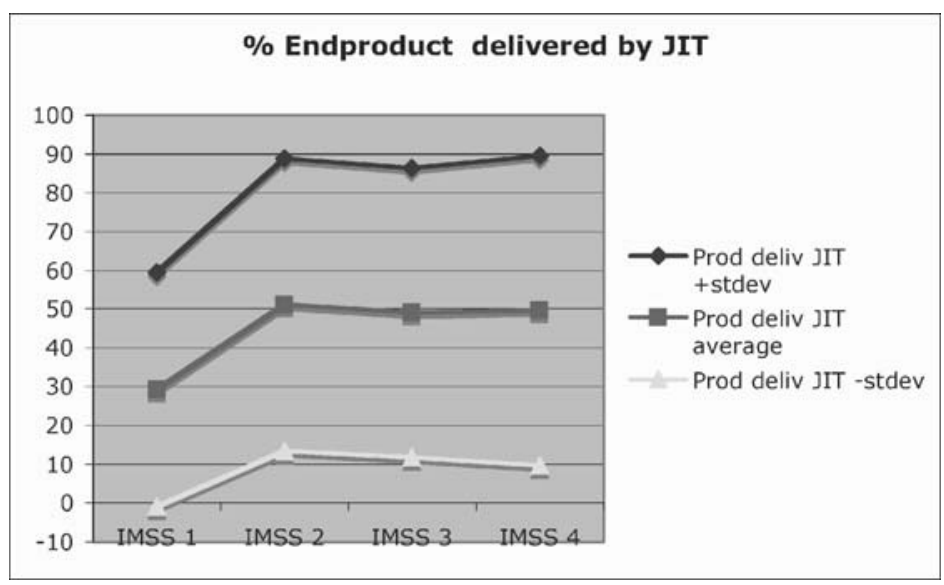

Fig. 4. The end-product delivered by Just-in-Time as percent of all end-product deliveries. It is showed as average and average plus and minus standard deviation

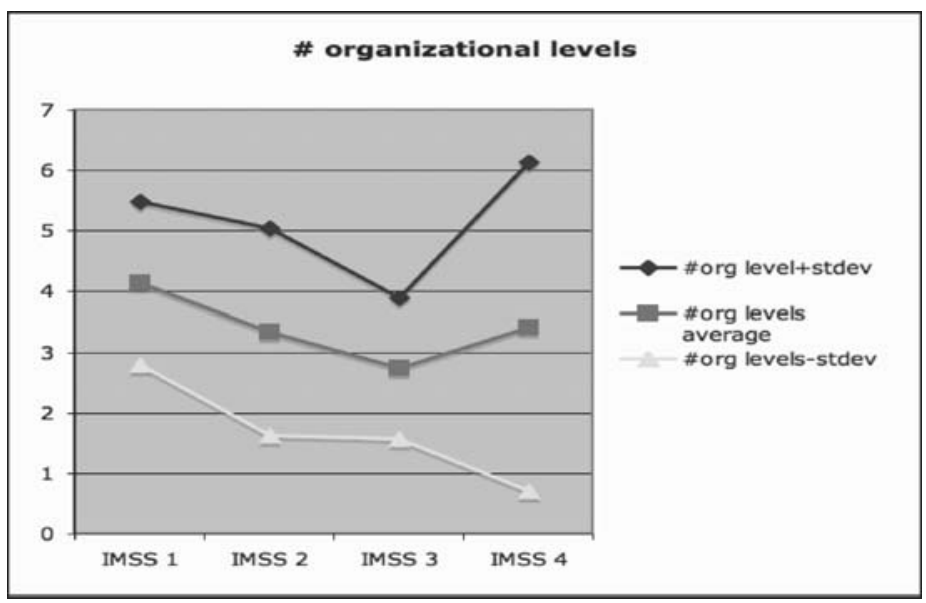

Fig. 5. The number of levels in the organization. It is showed as average and average plus and minus standard deviation

Figure 6 shows the percentage of deliveries that are late. Even if there is a slight decrease, an average of one in ten is still a high number and when we add the standard deviation one in four is not good.

Figure 7 shows the action program for Lean Management in 2005. All the IMSS questionnaires ask about many action programs. The basic idea is to document the connection from strategies to improvement action to change in performance. (Lindberg, Voss, \& Blackmon, 1998) This question asks on a scale 1-5 if there have been use of lean management as an action program in the last 3 years, and if there are plans for utilizing lean management in the next 3 years. We see a slight increase. 


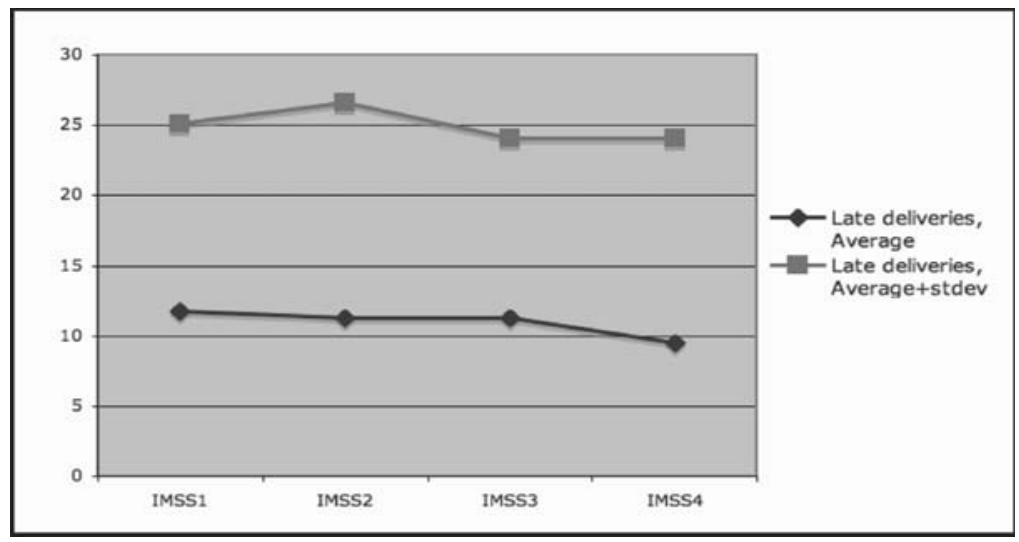

Fig. 6. The end-product delivered late as percent of all end-product deliveries. It is showed as average and average plus standard deviation

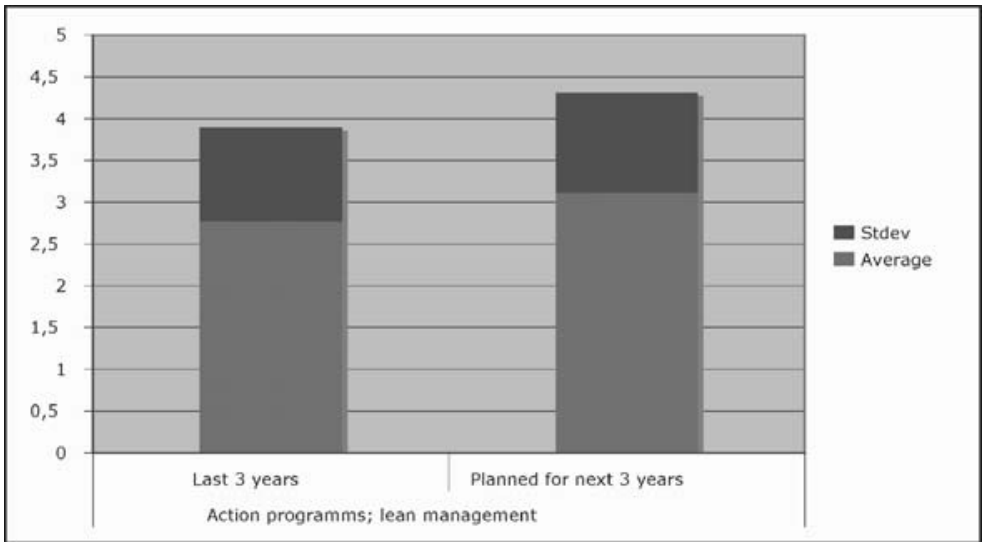

Fig. 7. The Action program for Lean Management as a 1-5 scale. It is showed as average and average plus standard deviation. The figure shows answers for last 3 years and if it is planned for next 3 years. We see a slight increase

In figure 8 we see the preventive quality cost as percentage of total quality cost. We see a slight increase here from 1996 to 2000, and it is interesting that this is in parallel with the increase of preventive maintenance as seen in figure 3 .

At last in figure 9 we see two status parameters both measured as percentage of total cost. This is the "scrap and rework cost" and the "customer complaints cost". Both is high when we look for lean performance. 


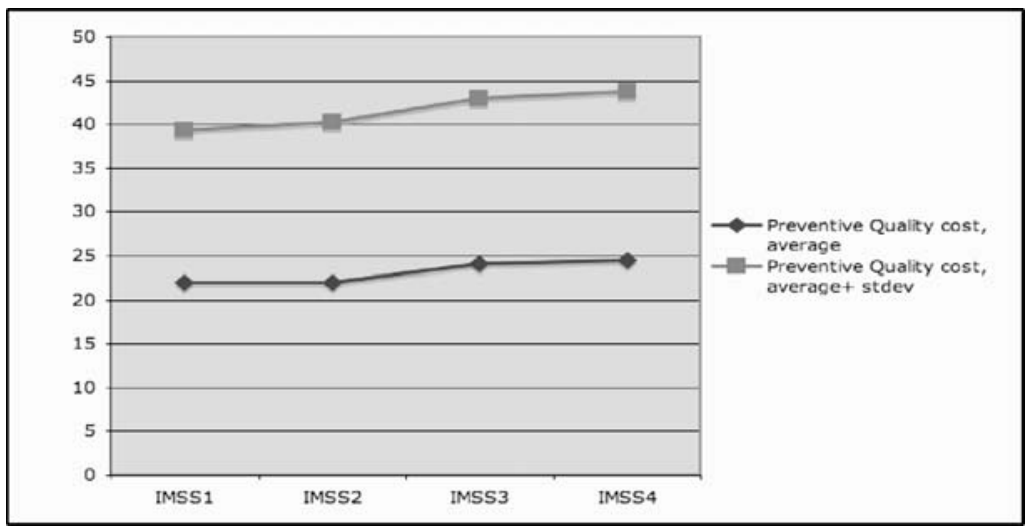

Fig. 8. The preventive Quality cost as percent of all quality cost. It is showed as average and average plus standard deviation

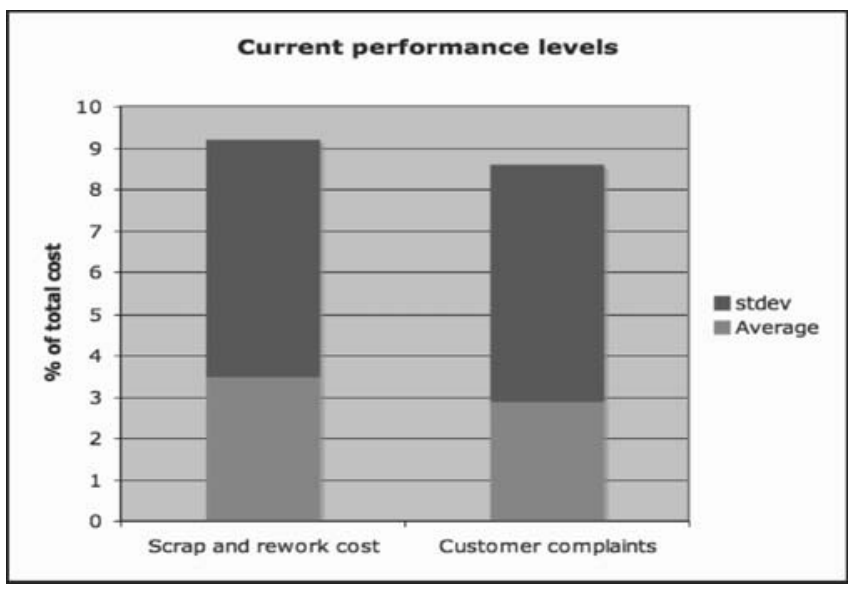

Fig. 9. The 2005 status of "scrap and rework cost" and of "customers complaints". Both measured as percentage of total cost

\section{Conclusion}

We see that several issues related to lean management have made a way into companies from 1992 to 2005 . We also see from the action program and the status charts that emphasis on lean management are increasing and that there are still large possibilities for improvements. 


\section{References}

1. Acur, N., Gertsen, F., Sun, H., \& Frick, J. (2003). The formalisation of manufacturing strategy and its influence on the relationship between competitive objectives, improvement goals, and action plans. International Journal of Operations \& Production Management, 23(10), 1114-1141.

2. Crowe, D., Brennan, L., Coughlan, P., \& Dromgoole, T. (2003). International Manufacturing Strategy Survey, Irish Report. Dublin: University of Dublin, Trinity College.

3. Svensen, Ø. (2002). Lean produksjon- En sammenligning mellom Japan og Europa. Unpublished Bachelor, Stavanger University College, Stavanger.

4. Frick, J. (2006). Trends in cost structure based on the international manufacturing strategy survey logitudinal data. Paper presented at the Euroma 2006, moving up the value chain, Glascow.

5. Gertsen, F., Sun, H., Riis, J. O., \& IPS - Integrated Production Systems. (1994). Compare your company with the world's best Danish report of the International Manufacturing Strategy Survey (IMSS). Aalborg: Department of Production.

6. Hedeker, D., \& Gibbons, R. D. (2005). Applied longitudinal data analysis. Hoboken, N.J.: Wiley-Interscience.

7. Klingan, E. (2000). Strategiske forskjeller mellom Argentinske og Brasilianske metallprodusenter. Unpublished Bachelor, Stavanger University College, Stavanger.

8. Laugen, B. T., \& Frick, J. (2002, 4 Juni 2002). Linking of strategy and supply chain management: change management or opportunity driven development. Paper presented at the Euroma 2002, København.

9. Lindberg, P., Hörte, S.-Å., International Manufacturing Strategy Survey, \& Institute for Management of Innovation and Technology. (1994). Produktion jorden runt : strategier i 600 företag från 20 länder. Göteborg: Chalmers tekniska högsk. IMIT.

10. Lindberg, P., Voss, C., \& Blackmon, K. L. (1998). International manufacturing strategies : context, content and change. Boston: Kluwer.

11. Nyvoll, E. T. (2004). En sammenligning av Brasil og Nord-Europa når det gjelser organisasjonsmessige faktorer. Unpublished Bachelor, Stavanger University College, Stavanger.

12. Skåle, V. (2000). IMSS, Opplaring i Tyskland og Canada. Unpublished Bachelor, Stavanger University College, Stavanger. 
13. Sun, H. (1996). Benchmarks for world-class benchmarking : a Norwegian report of international manufacturing strategy survey (IMSS). Stavanger: [H*gskolen i Stavanger].

14. Sun, H., \& Hansen, P. H. K. (1992). Research Metodology in an empirical study of technological-organizational development and market dynamics. Paper presented at the Methods for Integration in Manufacturing, Proceedings of the 6th IPS research seminar, Fuglsøe.

15. Womack, J. P., Roos, D., \& Jones, D. T. (1991). The machine that changed the world: [the story of lean production]. New York, N.Y.: HarperPerennial.

16. Østebø, M. H. (2000). Er anvendelse av "Lean Enterprise" relevant for bore - og brønnoperasjoner? Unpublished Master, Stavanger University College, Stavanger. 